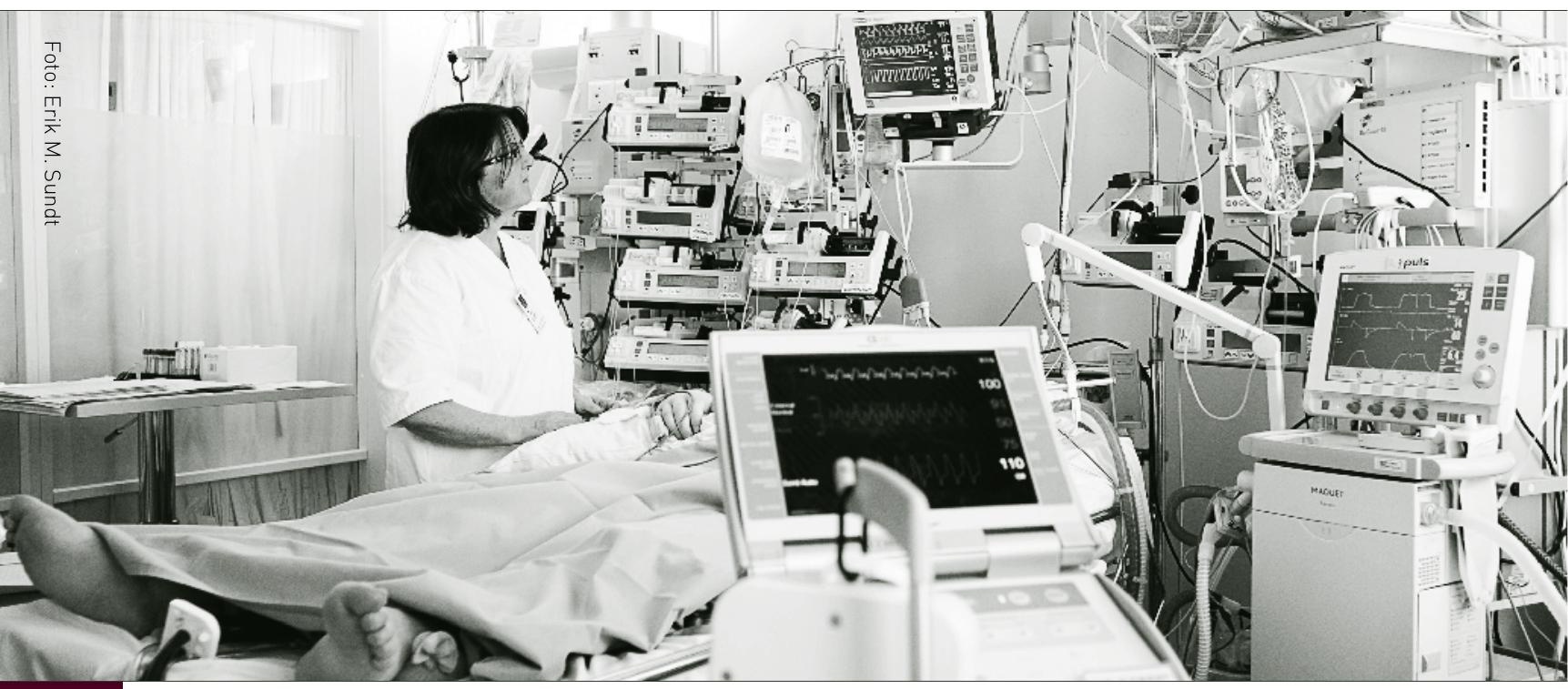

Bakgrunn: Delirium forekommer hos 20-80 prosent av intensivpasientene og er assosiert med økt dødelighet, lengre sykehusopphold og langtidsplager for pasienten. Tilstanden blir ofte oversett, til tross for at det finnes kunnskapsbaserte anbefalinger om systematisk vurdering med valide verktøy.

Hensikter: Hensiktene med kvalitetsforbedringsprosjektet var (i) å kartlegge hvordan sykepleiere dokumenterte observasjoner av kognitive status, (ii) å vurdere om praksis var i tråd med anbefalinger, og (iii) iverksette eventuelle tiltak for å bedre praksis.
Metode: Vi gjennomførte en klinisk audit av sykepleiedokumentasjonen til 47 intensivpasienter i løpet av tre måneder om bruk av Confusion Assessment Method for the Intensive Care Unit (CAM-ICU). Sykepleierapportene om 18 tilfeldige pasienter fra utvalget ble unders $\varnothing \mathrm{kt}$ for alternativ vurdering av delirium. Alle sykepleierne fikk undervisning i CAM-ICU. Deretter målte vi i hvilken grad CAM-ICU ble utført i en periode på 15 uker.

Resultat: Vi fant at CAM-ICU ikke var brukt på noen av pasientene $(n=47)$. Sykepleierapporter om 18 av de 47 pasientene viste usystematisk og utilstrekkelig tilnærming til delirium. Et fåtall sykepleienotat (4,3 prosent) inneholdt en komplett vurdering i tråd med anbefalingene. Etter endringstiltak økte komplett vurdering til 27,5 prosent av tilfellene. Delirium ble identifisert hos flere pasienter etter iverksetting av tiltak, fra 23,4 prosent til 52,9 prosent.

Konklusjon: Klinisk audit avdekket praksis i utakt med kunnskapsbaserte anbefalinger. Enkle tiltak førte til at flere pasienter ble systematisk vurdert for delirium
Evidence-based assessment of delirium in intensive care

Background: Delirium occurs in $20-80 \%$ of patients in intensive care, and is associated with increased mortality, increased hospital stay and long-term problems for the patient. Still, the condition is often overlooked in the intensive care, even though there are evidence-based guidelines recommending that critically ill patients be systematically assessed for delirium.

Objectives: The objectives of this quality improvement project were to (i) investigate nursing notes of observations related to cognitive status, (ii) assess whether practice was according to recommendations, and (iii) to make necessary changes to improve practice.

Method: An audit was performed on the notes of 47 consecutive patients during a three-month period according to a pre-set criterion. Additionally, we randomly picked 18 of these cases for further investigation of the nursing documentation. After providing an educational session, we conducted a re-audit during 15 consecutive weeks.

Results: Confusion Assessment Method for the Intensive Care Unit (CAM-ICU) was not documented as applied to any patients during the study period $(n=47)$. The nursing notes for 18 of these cases showed that delirium was unsystematically and subjectively assessed. Only $4.3 \%$ of the nursing notes contained a complete delirium assessment, according to the recommendations. After the educational session, the frequency of complete assessments increased to $27.5 \%$. Furthermore, we found an increase in recognition of delirium from $23.4 \%$ to $52.9 \%$ of the patients.

Conclusion: A clinical audit uncovered a practice that was inadequate when compared to evidence-based recommendations. An educational session improved practice and more patients were systematically assessed for delirium.

Keywords: Delirium, clinical audit, intensive care unit, quality improvement, CAM-ICU 


\section{Kunnskapsbasert vurdering av delirium hos intensivpasienten}

Forfattere: Britt Sjøbø,

Birgitte Graverholt og Gro Jamtvedt

\section{NøKKELORD}

- Intensiv

- Kvalitet

- Pasient

- Sykehus

\section{INTRODUKSJON}

Delirium er rapportert å forekomme hos 20-80 prosent av pasienter som ligger på intensivavdelingen, avhengig av underliggende sykdomstilstand og vurderingsmetode (1). Tilstanden beskrives som forstyrret bevissthet karakterisert av akutt innsettende og varierende grad av svekket evne til rasjonell tanke og oppfatning av det som skjer. Dette kan vise seg som varierende bevissthet, konsentrasjonsvansker, hukommelsessvikt, desorientering, språkvansker og hallusinasjoner (1). Symptomene er lett gjenkjennelig hos den motorisk urolige og forvirrete pasienten, men kan overses når pasienten er rolig og tilsynelatende samarbeidende (2). Konsekvensene av delirium hos intensivpasienten er betydelige i form av økt dødelighet, økt liggetid på respirator og i sykehus, og langtidsplager som angst og konsentrasjons- vansker for pasienten (3-6). Det er derfor et stort problem at delirium ikke blir oppdaget hos denne pasientgruppen (2,7-10).

Sykepleiere har en viktig rolle i diagnostisering av delirium fordi de er hos intensivpasienten hele tiden og slik kan fange opp endringene som er karakteristiske for utviklingen av delirium (11). Forskning har imidlertid vist at sykepleieres observasjoner av deliriums kliniske uttrykk ofte ikke er strukturerte og detaljerte nok til at diagnosen kan stilles. Dette gjelder spesielt for intensivpasienter som har redusert eller manglende evne til å kommunisere verbalt $(2,7,9,12)$.

Flere studier har sammenliknet verktøy som kan avdekke delirium hos intensivpasienten $(8,13,14)$. Disse har vist at Confusion Assessment Method for the Intensive Care Unit (CAM-ICU) er en sensitiv og spesifikk metode som egner seg godt til å systematisk vurdere utvikling av delirium hos intensivpasienten. CAM-ICU kartlegger intensivpasientens kognitive status gjennom vurdering av fire sentrale kjennetegn for delirium:

1. Akutt innsettende endring eller variasjon i mental status

2. Uoppmerksomhet

3. Uorganisert tankegang

4. Endret bevissthet
For at intensivpasienten skal få diagnosen delirium ved akutt sykdom må kjennetegn en og to, i tillegg til tre eller fire, være positive $(15,16)$.

I en norsk intensivavdeling er CAM-ICU integrert $\mathrm{i}$ avdelingens prosedyre (17), men man erkjenner at verktøyet ikke blir brukt systematisk i praksis. Målet med dette kvalitetsforbedringsprosjektet er å sikre at sykepleierne bruker CAM-ICU, slik at intensivpasi-

Hva tilfører artikkelen: Artikkelens funn antyder at antallet intensivpasienter som får delirium kan reduseres gjennom enkle sykepleietiltak som systematiske sjekklister og vurderingsverktøy.

\section{Mer om forfatterne:}

Britt Sjøbø er intensivsykepleier med mastergrad i kunnskapsbasert praksis i helsefag og jobber ved Intensivmedisinsk Seksjon, Haukeland universitetssjukehus. Birgitte Graverholt er intensivsykepleier og PhD-kandidat ved Senter for kunnskapsbasert praksis, Høgskolen i Bergen. Gro Jamtvedt er professor og prosjektleder ved Senter for Kunnskapsbasert praksis, Høgskolen i Bergen og avdelingsdirektør ved Nasjonalt kunnskapssenter for helsetjenesten. Kontakt: brit.sjobola helse-bergen.no. 
enter som utvikler delirium blir oppdaget og kan få behandling for dette. Gjennom et kvalitetsforbedringsprosjekt ønsket vi derfor (i) å kartlegge hvordan sykepleiere dokumenterte observasjoner av intensivpasientens kognitive status, (ii) å vurdere om denne praksis var i tråd med kunnskapsbaserte ved systematisk kartlegging av praksis, vurdering av denne opp mot tydelige kriterier som er anbefalinger fra forskning, og implementering av endringstiltak hvis dette er nødvendig. En klinisk audit på et avgrenset og veldefinert område er en trinnvis prosess (Se figur 1) $(18,19)$.

\section{Konsekvensen av delirium hos intensivpasienten er betydelig.}

anbefalinger, og (iii) iverksette tiltak for å bedre praksis dersom det var nødvendig.

\section{METODE}

Klinisk audit er en kvalitetsforbedringsmetode som har til hensikt å vurdere om praksis stemmer overens med kunnskapsbaserte anbefalinger på et bestemt område (18). Dette skjer
Som tema er delirium egnet for bruk av audit som kvalitetsforbedringsmetode fordi forekomst av delirium er stor, tilstanden er ressurskrevende å håndtere, og konsekvensene for pasienten og kostnaden for samfunnet er betydelig $(18,19)$.

\section{Setting}

Kvalitetsforbedringsprosjektet ble gjennomført høsten 2010 $i$ en generell intensivavdeling med plass til ti pasienter ved et norsk universitetssykehus. For å kartlegge praksis inkluderte vi journaler fra alle pasienter som ble innlagt i intensivavdelingen i en periode på 12 uker. Eksklusjonskriterier var: Psykisk utviklingshemming, alder under 12 år, demens, bruk av vanedannende rusmidler, schizofreni eller annen psykisk sykdom, ikke norskspråklig, intensivopphold kortere enn 24 timer, vedvarende koma eller som døde under intensivoppholdet.

\section{Kriterier}

Praksis ble målt på eksplisitte kriterier, eller målbare og relevante utsagn fra forskning som sier noe om hvordan praksis bør være. Praksis ble evaluert opp mot en standard, som beskriver

FIGUR 1: Modell for klinisk audit med relevante aktiviteter:

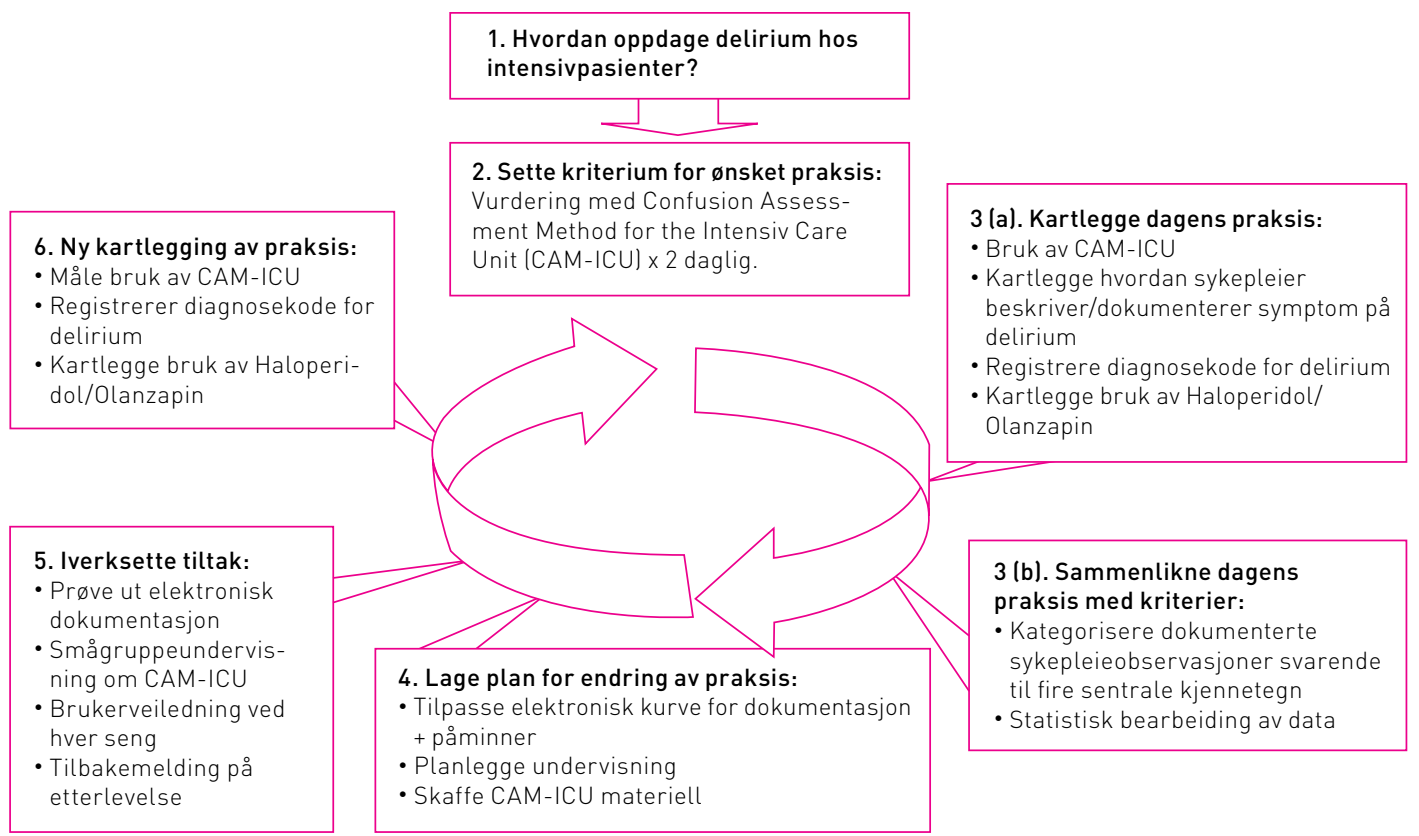


ønskelig nivå for etterlevelse av prosedyre (18). I klinisk audit bør både prosess og resultat måles (18).

Som grunnlag for kriterium søkte vi etter retningslinjer i Guidelines International Network (GIN) og på nettsidene til store organisasjoner innen intensivmedisin og psykiatri. Vi fant flere aktuelle som ble kritisk vurdert (20). Basert på dette valgte vi å bruke retningslinjen «Delirium: diagnosis, prevention and management» (11). Standard ble satt på bakgrunn av det andre studier har vist at det er mulig å oppnå (21-24). Følgende kriterium og standard ble formulert for prosjektet:

\section{Kartlegging av praksis}

Elektronisk pasientkurve og pasientjournalenes sykepleienotater ble undersøkt for dokumentasjon av bruk av CAM-ICU. Fordi symptomer på delirium kan avdekkes på andre måter enn å bruke CAM-ICU, og siden det var forventet lav etterlevelse av CAM-ICU ved oppstart av prosjektet, ble 18 tilfeldige journaler trukket ut for en sekundær gjennomgang av sykepleiedokumentasjonen. I disse ble sykepleienotatenes beskrivelse av kognitiv status undersøkt. Vi så etter beskrivelser av de fire kjennetegnene for delirium i sykepleienotatene $(15,16)$ og avgjorde om disse

Kriterium: Vurdering med CAM-ICU morgen og kveld hos alle pasienter med bevissthetsnivå svarende til Richmond Agitation and Sedation Scale (RASS) -3 til +4 (11).

Standard: $\quad$ CAM-ICU skal utføres i 95 prosent av mulige vurderingstidspunkt (21-24).

var adressert. En hjelpetabell med beskrivelser av de ulike kjennetegnene ble brukt i dette arbeidet $(2,12)$ og data ble samlet $\mathrm{i}$ et eget hjelpeskjema. (Se figur 2.)

For å kvalitetssikre denne prosessen ble et mindre og tilfeldig antall av sykepleienotatene uavhengig analysert av to sykepleiere. Videre ble det undersøkt om observasjonene førte til at helsepersonell erkjente diagnosen, enten i form av diagnosekode og/eller bruk av medikamentene Haloperidol/ Olanzapin, som kun blir brukt ved delirium i den aktuelle avdelingen.

\section{Sammenlikning}

Data for dokumentert CAMICU-skår, medikamentell behandling og diagnosekode er kategoriske data og ble beskrevet med tall (n) og andel $(\%)$. Sykepleiedokumentasjonen, som ble undersøkt sekundært, ble kategorisert til de fire kjennetegnene for delirium

FIGUR 2: Hjelpetabell med eksempler for kategorisering av beskrivelser i sykepleiedokumentasjon $(2,2)$.

\begin{tabular}{|c|c|c|c|}
\hline $\begin{array}{l}\text { Kjennetegn 1: Endret mental } \\
\text { status fra habituell tilstand, akutt } \\
\text { innsettende/varierende forløp. }\end{array}$ & $\begin{array}{l}\text { Kjennetegn 2: } \\
\text { Uoppmerksomhet. }\end{array}$ & $\begin{array}{l}\text { Kjennetegn 3: Manglende } \\
\text { organisering av tankene. }\end{array}$ & $\begin{array}{l}\text { Kjennetegn 4: Endret } \\
\text { bevissthetsnivå. }\end{array}$ \\
\hline $\begin{array}{l}\text { Dokumentasjon på pårørendes } \\
\text { beskrivelse om habituell mental } \\
\text { status. }\end{array}$ & $\begin{array}{l}\text { Husker ikke informasjon. } \\
\text { Blir lett distrahert, klarer } \\
\text { ikke holde fokus, lar seg } \\
\text { lett avlede. }\end{array}$ & $\begin{array}{l}\text { Desorientert. } \\
\text { Mumlende/usammen- } \\
\text { hengende tale. } \\
\text { Inadekvat adferd; plukker }\end{array}$ & $\begin{array}{l}\text { Skåringsverdi for bevisst- } \\
\text { hetsnivå (RASS) på vurde- } \\
\text { ringstidspunktet. }\end{array}$ \\
\hline $\begin{array}{l}\text { Beskrivelser om variasjoner i } \\
\text { mental status gjennom døgnet, } \\
\text { f. eks. plutselige endringer, eller } \\
\text { refleksjon rundt varierende skå- } \\
\text { ringsverdier for bevissthetsnivå } \\
\text { (RASS) siste } 24 \text { timer. }\end{array}$ & $\begin{array}{l}\text { Rastløs i sengen. } \\
\text { Lukker øynene/sovner } \\
\text { midt i samtalen. } \\
\text { Passiv/initiativløs. } \\
\text { Holder ikke blikkontakt/ } \\
\text { flakkende blikk. }\end{array}$ & $\begin{array}{l}\text { på ledninger/bandasjer/vil } \\
\text { ut av sengen. } \\
\text { Følger ikke oppfordring. } \\
\text { Hallusinasjoner. }\end{array}$ & \\
\hline $\begin{array}{l}\text { Normalitet: stabil, habituell } \\
\text { tilstand gjennom døgnet. }\end{array}$ & $\begin{array}{l}\text { Normalitet: konsentrert, } \\
\text { rolig, alert. }\end{array}$ & $\begin{array}{l}\text { Normalitet: Tydelig/ } \\
\text { sammenhengende tale. } \\
\text { Orientert. }\end{array}$ & $\begin{array}{l}\text { Normalitet: Våken, i sin } \\
\text { vanlige bevissthetstilstand. }\end{array}$ \\
\hline
\end{tabular}


og omkodet til ukentlig andel komplette deliriumvurderinger. Dette ble brukt som baselinemåling for å sammenlikne dagens praksis med ønsket kriterium.

\section{Endringstiltak}

Personalet i avdelingen disku-

erfaringer fra lignende forbedringsprosjekt på samme problemområde (21-24).

I løpet av fire uker fikk alle sykepleierne $(\mathrm{n}=66)$ undervisning i små grupper (to til sju deltakere) om verktøyet CAM-ICU. Diskusjon rundt pasientkasus var inkludert i

\section{Sykepleiere har fokus på delirium, men mangler kunnskap om vurderingsverktoy.}

terte årsaker til at CAM-ICU ikke ble utført og vi søkte etter forskning som kunne informere endringsprosessen. Systematiske oversikter viste at bestemte kunnskapsbaserte tiltak kan forbedre praksis (25-29). I tillegg brukte vi dette (25). Den elektroniske pasientkurven ble tilrettelagt for dokumentasjon og påminnelse dersom CAM-ICU ikke ble utført, i tillegg til at resultatet av CAM-ICU ble linket til aktuelle arbeidsdokument for legene (26). En veiledning for bruk av CAM-ICU ble tilgjengelig ved hver seng (27) og personalet fikk tilbakemelding på etterlevelse av prosedyre i form av veggplakat en måned etter iverksettelse av tiltak $(28,29)$.

\section{Kartlegging av ny praksis}

Etter fire uker med iverksetting av endringstiltak ble praksis fulgt i 15 påfølgende uker i en ny kartlegging av bruk av CAMICU. Statistisk prosesskontroll, en form for tidsserieanalyse, ble brukt for å overvåke endringsprosessen. Dette er en anerkjent metode som kan brukes ved små datamengder for å undersøke om en endring blir en forbedring og for å kunne forstå variasjon i prosessen (30). Et prosentdiagram viser prosessens endring $\mathrm{i}$

FIGUR 3: Ukentlig andel dokumenterte komplette vurderinger, før og etter endring innført i ukene 36-39.

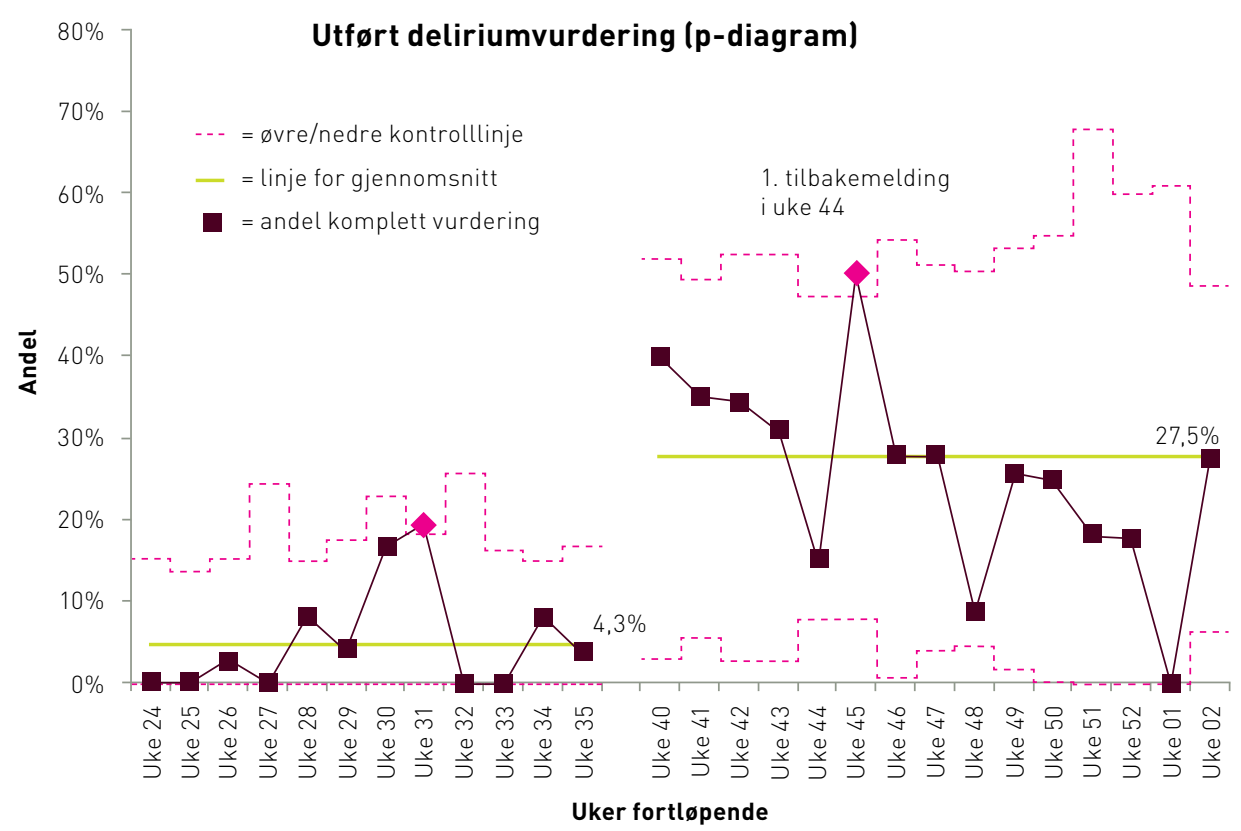

Hvert målepunkt er antall utførte vurderinger dividert på antall vurderinger som skulle vært utført. Grønn linje viser gjennomsnittlig andel utførte vurderinger i perioden før og etter endringer. Øvre og nedre kontrollgrense er $+/-3$ standardavvik av ukentlig andel utførte vurderinger. 
prosjektperioden, hvor ukentlig andel gjennomførte deliriumvurderinger ble brukt som måleenhet, altså antall utførte deliriumvurderinger dividert på antallet vurderinger som skulle vært utført (figur 3). Kontrollgrensene i diagrammet viser grensene for området hvor framtidige målinger kan forventes å ligge hvis ikke endringer blir iverksatt.

For å vite sikkert at de to utvalgene var sammenliknbare ble demografiske variabler undersøkt, i tillegg til diagnosespesifikk kode for delirium ved akutt sykdom (32) og eventuell medikamentell behandling for delirium (resultatkriterium). Kategoriske data, som kjønn, innleggelsesårsak, forekomst av delirium, diagnosekode og medikamentbruk blir beskrevet med tall (n) og andel (\%). Kontinuerlige data som alder, liggetider og skåringsverdier for organsvikt og mortalitetsrisiko er beskrevet med median, interkvartiler (Q25-Q75) og range.

Demografiske variabler og forekomst av delirium før og etter endring ble, avhengig av dataenes målenivå, analysert med t-test, Mann Whitneys rangsumtest, Fishers eksakte test og kji-kvadrat for uavhengige grupper (33). På alle tester ble det satt signifikansnivå 0,05 .

Dataprogrammet Quality Improvement Macros 2011 ble brukt i analysearbeidet.

\section{Etikk}

Prosjektet ble framlagt Regional Etisk Komité (REK) Vest, hvor det ble klassifisert som kvalitetsforbedringsprosjekt. Tillatelse til å gjennomføre prosjektet og opprette egen database ble gitt av Personvernombudet ved det lokale helseforetaket.

\section{RESULTAT}

\section{Sammenlikning av praksis mot kriterium}

Vi fant at CAM-ICU ikke var dokumentert brukt på noen av pasientene i en tolvukers periode $(n=47)$, slik avdelingsprosedyren sier (prosesskriterium). Av disse hadde 11 (23,4 prosent, 95 prosent konfidensintervall: 10,7-36,2) likevel fått diagnosen delirium, bestemt av diagnosekode satt av lege og/eller bruk av Haloperidol eller Olanzapin (resultatkriterium). Langt flere fikk medikamentell behandling $(n=10)$ enn diagnosekode for delirium $(\mathrm{n}=3)$.

Av de 47 pasientjournalene ble 18 pasientjournaler (372 sykepleienotat) undersøkt videre for å se hvordan sykepleierne dokumenterte observasjoner relatert til kognitiv tilstand, som et alternativ til en CAMICU-skår. Sykepleienotatene $(\mathrm{n}=$ fra perioden før endringer, der komplett deliriumvurdering var dokumentert i gjennomsnittlig 4,3 prosent av sykepleienotatene.

Statistisk overvåkning av praksisendring, ukentlig bruk av CAM-ICU, viste likevel en nivåendring $\mathrm{i}$ ønsket retning (figur 3).

Av de 51 pasientene hadde 27 (52,9 prosent, 95 prosent konfidensintervall: 38,3-67,5) delirium basert på diagnosekode, medikamentell behandling eller positiv CAM-ICU vurdering, en tydelig forskjell $(\mathrm{p}=0,02)$ fra forrige måling. Av pasientene med delirium hadde $21(77,8$ prosent), fått medikamentell behandling og 9 (33,3 prosent) fått diagnosekode, noe som var uendret fra før.

Pasientgruppene før og etter at endringstiltak var like (tabell 1), også når det gjaldt årsaker

\section{CAM-ICU må anses som et supplement til totalvurderingen av pasienten.}

372) fordelte seg jevnt over ukene med en median på 15 notat per pasient (Q25-Q75: 9-25, range: 4-55). Av alle sykepleienotatene inneholdt 16 (4,3 prosent) komplett vurdering av alle kjennetegnene, mens kjennetegn 1, 2, 3 og 4 var beskrevet $\mathrm{i}$ henholdsvis 100 prosent, 8,1 prosent, 43,4 prosent og 25,7 prosent av notatene.

\section{Ny kartlegging av praksis}

Det var i alt 51 pasienter som ble inkludert i kartlegging av praksis etter endringstiltak. Her fant vi at CAM-ICU ble utført i gjennomsnittlig 27,5 prosent av de forutbestemte vurderingstidspunktene i kriteriet, eller i 122 av de 443 vurderingstidspunktene. Dette var en forbedring til innleggelse, bortsett fra andel pasienter med infeksjoner, som var større i den siste (tabell 2).

\section{DISKUSJON}

Til tross for at delirium er en vanlig og svært alvorlig tilstand hos intensivpasienter, fant vi ikke dokumentert at noen av pasientene som var innlagt $i$ avdelingen $\mathrm{i}$ en tremåneders periode $(n=47)$ ble vurdert med CAM-ICU-skår, selv om dette var en del av avdelingens prosedyre. I stedet skjedde vurdering på sykepleieres subjektive grunnlag, noe som ved nærmere ettersyn i sykepleienotatene var utilstrekkelig: Bare et fåtall av notatene inneholdt en komplett vurdering av kjennetegnene for delirium. Ved å iverksette enkle 
tiltak oppnådde vi en prosentvis god forbedring av praksis, men prosessen var ustabil over tid. Delirium ble oppdaget hos flere pasienter etter at enkle tiltak ble iverksatt, men andelen vurderer om intensivpasienter har delirium. Gjennom å både kartlegge dokumentert bruk av CAM-ICU, men også undersøke sykepleienotatene, som sier noe om alternativ vurdering der-

\section{Delirium ble oppdaget hos flere pasienter etter at enkle tiltak ble iverksatt.}

pasienter som fikk medikamentell behandling og diagnosekode for delirium var uendret.

\section{Styrker og svakheter}

Fordi konsekvensen av audit kan være at praksis bør endres, må man stole på at auditresultatet avspeiler reell praksis (34). Denne metoden krever at aspekter av praksis kvantifiseres; i dette tilfelle hvordan sykepleiere som CAM-ICU ikke var brukt, mener vi at målingene gir et valid bilde av hvordan sykepleier adresserer delirium $\mathrm{i}$ avdelingen.

Studien er gjennomført som et kvalitetsforbedringsprosjekt og er ikke styrketestet med tanke på generaliserbarhet. Resultatene må derfor tolkes i lokal kontekst.

Sammenlikning av demografiske data ved pasientgruppene i periodene før og etter endringstiltakene viste at sykepleiere arbeidet med samme type pasienter under begge periodene. Dette underbygger at prosessforbedringen som ble vist ikke var et resultat av ulike pasientgrupper.

De observerte gevinstene; økt etterlevelse av prosedyre og økt antall pasienter som ble systematisk vurdert for delirium; kan være et resultat av at praksis blir studert. Det er likevel ikke en garanti for at slik endret praksis blir opprettholdt. Det er derfor mulig at prosessene og resultatene kan svekkes over tid.

\section{Andre studier}

Tidligere forskning har vist at implementering av CAM-ICU ikke kan forventes å skje passivt

TABELL 1: Pasientkarakteristika for utvalgene før og etter endring.

\begin{tabular}{|c|c|c|c|}
\hline Karakteristika & Før endring & Etter endring & \\
\hline Antall pasienter ( $n$ ) & 47 & 51 & \\
\hline \multicolumn{4}{|l|}{ Kjønn: } \\
\hline Menn / kvinner \% (n) & $53,2(25) / 46,8(22)$ & $64,7(33) / 35,3$ (18) & $x^{2}=1,342(p=0,25)$ \\
\hline Alder år median $\left(Q_{25}-Q_{75}\right)$ & $61(28-71,5)$ & $63(46-72,5)$ & z-skår: 1,459 (p = 0,14) \\
\hline Alder range & $13-93$ & $17-84$ & \\
\hline SAPS II median $\left(Q_{25}-Q_{75}\right)$ & $43(33-51)$ & $46(33-55)^{*}$ & z-skår: 0,759 (p = 0,45) \\
\hline SAPS II range & $10-69$ & $19-85^{*}$ & \\
\hline Max SOFA median $\left(Q_{25}-Q_{75}\right)$ & $7(5-10)$ & $7(4-10)$ & z-skår: 0,909 (p = 0,36) \\
\hline Max SOFA range & $1-18$ & $1-16$ & \\
\hline \multicolumn{4}{|l|}{ Respiratordøgn } \\
\hline Median $\left(Q_{25}-Q_{75}\right)$ & $2,17(0,28-6,46)$ & $2,96(0,76-8,09)$ & $t=-0,019(p=0,99)$ \\
\hline $\begin{array}{l}\text { Ligged } \varnothing g n \text { intensivavd. } \\
\text { median }\left(Q_{25}-Q_{75}\right)\end{array}$ & $5,25(2,86-9,78)$ & $4,44(2,17-10,34)$ & $z$-skår: 1,230 $(p=0,22)$ \\
\hline \multicolumn{4}{|l|}{ Liggedøgn sykehus } \\
\hline Median $\left(Q_{25}-Q_{75}\right)$ & $33(20-69,5)$ & $27(13,5-62,5)$ & $t=0,653(p=0,52)$ \\
\hline
\end{tabular}

*) Mangler data for to pasienter.

Kategoriske data: Kji-kvadrat ( $x^{2}$ ), ordinale data: Mann Whitney rangsumtest ( $\mathrm{z}$ ), kontinuerlige data: t-test (t). Q25-Q75=25- 75 persentil, SOFA: Sequential Organ Failure Assessment score, SAPS II: Simplified Acute Physiology Score II. 
og uten at sykepleiere støttes i prosessen. Devlin (35) fant at en tredel av sykepleierne i en intensivavdeling aldri fikk opplæring i hvordan vurderingsverktøy for delirium skal brukes, selv om det var forventet at de brukte det. Samtidig er det kjent at CAM-ICU krever både undervisning og trening for at vurderingene skal gjøres riktig (21-24). Det er dermed urimelig å forvente at sykepleiere skal ta vurderingsverktøyet i bruk uten opplæring. Det var derfor ikke overraskende at vår første kartlegging viste at CAM-ICU ikke ble brukt $\mathrm{i}$ avdelingen, til tross for at dette var bestemt gjennom eksisterende prosedyreverk.

Selv om CAM-ICU altså ikke ble dokumentert brukt, viste sykepleienotatene at pasientene likevel ble vurdert for symptom på delirium. Tilnærmingen var imidlertid usystematisk og preget av subjektive vurderinger. Også dette er et bilde av praksis som stemmer med tidligere forskning; sykepleiere bruker metoder som nevrologisk undersøkelse, observasjon og samtale med pasienten for å vurdere om pasienten har delirium $(2,7,35,36)$. Både våre funn og disse tidligere studiene viser at sykepleiere vektlegger orienteringsevne, avvikende atferd, bevissthet, pupiller, agitasjon og evne til å følge oppfordring. Dette viser at sykepleiere har fokus på delirium, men mangler kunnskap om vurderingsverktøy som kan fremme en systematisk og mer (kjennetegn 4) vurderes og skåres regelmessig, men vi fant ingenting som tydet på at sykepleiere koplet dette til vurdering av delirium. Andre studier har vist det samme (3), noe som tyder på generelt mangelfull kunnskap om hvordan de to henger sammen. Uoppmerksomhet (kjennetegn 2) var også lite omtalt i sykepleierapportene. Dette kjennetegnet er en forutsetning for å vurdere om pasienten har delirium, men er krevende å vurdere skjønnsmessig. Også pasientens evne til å organisere tankene (kjennetegn

\section{CAM-ICU var vanskeligere å implementere enn forventet.}

presis tilnærming til tilstanden.

Vår gransking av sykepleiedokumentasjonen viste liten refleksjon rundt de viktige fire kjennetegnene for delirium. Mental status (kjennetegn 1) og endring i bevissthetsnivå

TABELL 2: Årsaker til intensivoppholdet.

\begin{tabular}{|c|c|c|c|}
\hline Årsak til ICU-innleggelse & $\begin{array}{c}\text { før endring } \\
47(n)\end{array}$ & $\begin{array}{c}\text { etter endring } \\
51(n)\end{array}$ & \\
\hline Isolert hodeskade & 3 & 2 & $P=0,67$ \\
\hline Multitraume $\mathrm{m} /$ hodeskade & 2 & 1 & $P=0,61$ \\
\hline Multitraume u/hodeskade & 4 & 1 & $P=0,19$ \\
\hline Infeksjon/sepsis & 6 & 16 & $P=0,03^{*}$ \\
\hline Resp.svikt & 15 & 13 & $P=0,48^{*}$ \\
\hline Sirk.svikt & 5 & 2 & $P=0,26$ \\
\hline Resp.svikt + sirk.svikt & 3 & 5 & $P=0,72$ \\
\hline Multiorgan svikt & 1 & 1 & $P=1,0$ \\
\hline Nevrologisk svikt & 5 & 4 & $P=0,73$ \\
\hline Gastrointestinal svikt & 1 & 5 & $P=0,21$ \\
\hline Planlagt opr. & 1 & 1 & $P=1,0$ \\
\hline Nyresvikt & 1 & 0 & $P=0,48$ \\
\hline
\end{tabular}

3) var sjelden beskrevet. I en stor studie av sykepleieres deliriumvurderinger hos 797 eldre sykehuspasienter fant Inouye (2) også sparsomme beskrivelser av de sentrale kjennetegnene for delirium. Uoppmerksomhet ble beskrevet i 15 prosent av tilfellene der dette tegnet var til stede, uorganisert tankegang ble fanget opp i 26 prosent av tilfellene og endret bevissthetsnivå i 15 prosent av tilfellene. Milisen (12) fant i en liknende kartlegging at endret bevissthetsnivå ikke var dokumentert i det hele. Disse studiene viser at sykepleieres subjektive tilnærming er for upresis til å oppdage delirium. Å vurdere om en intensivpasient makter å holde konsentrasjonen og orientere seg i situasjonen krever en systematisk tilnærming, noe verktøyet CAM-ICU kan bidra til.

Overvåkning av prosess er ikke nok for å få til endring, men kan være nyttig for å holde fokus i forbedringsprosessen (30). Faren for å falle tilbake til «gamle synder» er altså stor 
dersom ikke oppfølgingstiltak iverksettes (22). Ny kartlegging av praksis viste en prosentvis forbedring på etterlevelse av prosedyre, men vi oppnådde ikke den standarden som vi satte til kriteriet. Forskning viser at implementering av CAM-ICU er ressurskrevende (21-24). Vi hadde få ressurser satt av til dette endringsarbeidet og den ønskete standard var kanskje for ambisiøs i en slik setting. Prosessen var ustabil, med målepunkt som svingte rundt gjennomsnittslinjen. Noen uker ble det utført så få vurderinger med CAM-ICU at praksis liknet tiden før tiltak (figur 2). Også spesiell variasjon i ønsket retning pekte seg ut; for eksempel ble det gitt feedback til personale i uke 44 . Pun (22) fant at oppfølging av prosess i forbindelse med innføring av vurderingsverktøy for delirium er viktig; etterlevelse av prosedyre falt når regelmessig feedback uteble ett år etter implementeringen. Dette understreker at kvalitetsarbeid er krevende og at betydningen når diagnostiseringsverktøyene blir bedre (38). Selv om vi oppdaget flere med delirium, var andelen av disse som fikk diagnosekode og/eller behandling uendret fra tidligere $(\mathrm{p}=0,65)$. Dette forbedringsprosjektet hadde imidlertid ikke som mål å endre praksis på disse områdene, men vi valgte å måle disse variablene, fordi det har stor betydning for pasientene og sier noe om vekselvirkning mellom sykepleieres observasjoner og legers tiltak.

\section{Resultatets betydning}

Manglende bruk av CAM-ICU og sjekklister for øvrig kan handle om en opplevelse av å nedvurdere verdien av sykepleiers erfaring og kliniske skjønn. Hensikten med å implementere CAM-ICU, en kunnskapsbasert «sjekkliste», er ganske riktig å redusere sykepleiers ensidige bruk av subjektive og skjønnsmessige vurderinger, fordi dette har vist seg utilstrekkelig og kan gå ut over pasientens sikkerhet. Skjønnet kan være spesielt viktig dersom

\section{Delirium hos intensivpasienten er vanskelig å identifsere.}

av oppfølgingstiltak ikke må undervurderes.

Det er et kjent fenomen at måling av prosess i seg selv kan gi bedre resultat (37), noe vi også fant: Sykepleierne dokumenterte ikke bruk av CAMICU så ofte som de skulle, men delirium ble identifisert hos flere pasienter etter tiltak ( $\mathrm{p}=$ $0,002)$. Utvalgene vi sammenliknet var imidlertid små, slik at resultatet kan handle om tilfeldig variasjon. En økning i forekomst er likevel forventet verktøy eller regler mangler for et område av praksis, eller når generelle regler anvendes på enkeltmennesket (39). Når det gjelder delirium hos intensivpasienten har CAM-ICU vist seg å være et godt verktøy som fanger opp denne alvorlige tilstanden, mens bruk av bare skjønn, eller erfaringsbasert kunnskap har vist seg upresist og utgjør en vilkårlig praksis som ikke er til det beste for pasienten (4, 9-12). Vi understreker likevel at CAM-ICU må anses som et supplement til totalvurderingen av pasienten, hvor langt flere hensyn spiller inn.

En viktig årsak til den relativt svake forbedringen av praksis var trolig mangel på ressurser til å følge opp implementeringsplanen som forelå. Flere har vist at systematisk implementering med forpliktende plan for opptrapping av tiltak kan gi gode resultater (21-24). Uformelle tilbakemeldinger viste at CAM-ICU var vanskeligere å implementere enn forventet, særlig på pasienter med hodeskade og dyp sedering. Dette framkom også i studien til Devlin (40), som i tillegg fant at behovet for veiledning var stort ved implementering av et systematisk vurderingsverktøy for delirium. Praktisk øving med CAM-ICU i ulike pasientsituasjoner synes derfor nødvendig for å skape trygghet og mestring blant sykepleiere. Ressursbruk som skal støtte en implementeringsprosess blir ofte glemt eller nedprioritert, slik det også ble i dette prosjektet. De foreslåtte tiltakene som skulle imøtekomme forventede utfordringer, slik som akademisering (41) og aktivisering av «superbrukere» (42), uteble fordi driften ikke tillot det. Grol og Wensing (43) hevder at mennesker beveger seg i ulikt tempo fra en endringsfase til neste, og at tiltakene må tilpasses i forhold til dette. Individets egne forventninger til prestasjon avhenger slik av faktiske muligheter til å prestere det som forventes, og negative erfaringer knyttet til dårlig mestring kan hindre endring i ønsket retning (44). Manglende folelse av mestring knyttet til CAM-ICU kan derfor føre til at sykepleiere avstår fra å bruke den uten 
tilstrekkelig veiledning, øvelse og oppmuntring.

\section{Konklusjon}

Delirium hos intensivpasienten er vanskelig å identifisere og en vurdering basert på sykepleieres subjektive grunnlag er ikke tilstrekkelig. En forutsetning for god pasientbehandling er korrekte observasjoner og dokumentasjon av disse, og derfor bør alle intensivavdelinger implementere et systematisk vurderingsverktøy for delirium i sin praksis. Utfordringene knyttet til å endre praksis må imidlertid ikke under-

\section{REFERANSER}

1. Morandi A, Jackson J, Ely EW. Delirium in the Intensive Care Unit. Int Rev Psychiatry. 2009;2:43-58.

2. Inouye S, Foreman MD, Mion LC, Katz KH, Cooney LM. Nurses' recognition of delirium and its symptoms: a comparison of nurse and researcher ratings. Arch Intern Med. 2001;161:2467-73.

3. Ely EW, Gautam S, Margolin R, Francis J, May L, Speroff T et al. The impact of delirium in the intensive care unit on hospital length of stay. Intensive Care Med. 2001;27:1892-900.

4. Lin SM, Liu CY, Wang CH, Lin HC, Huang $C D$, Huang PY, Fang, et al. The impact of delirium on the survival of mechanically ventilated patients. Crit Care Med. 2004;32:2254-9

5. Jackson JC, Gordon SM, Hart RP, Hopkins RO, Ely EW. The association between delirium and cognitive decline: A reviewof the empirical litterature. Neuropsychol Rev. 2004;14:87-98.

6. Griffiths RD, Jones C. Delirium, cognitive dysfunction and postraumatic stress disorder. Curr Opin Anaesthesiol. 2007;20:124-9.

7. Spronk PE, Riekerk B, Hofhuis J, Rommes $\mathrm{JH}$. Occurence of delirium is severly underestimated in the ICU during daily care. Intensive Care Med. 2009;35:1276-80. vurderes. Tilrettelegging, blant annet med praktisk trening for alle og «superbrukere» som kan

Studien ble gjennomført som et mastergradsprosjekt ved Mastergrad i kunnskapsba-

\section{(1) Tett oppfolging av forbedringsprosessen kan skape mer varige resultater.}

veilede i hverdagen, kan være tiltak som bidrar til en effektiv implementering. Tett oppfølging av forbedringsprosessen kan skape mer varige resultater. Dette bør erkjennes i planleggingsfasen med å avsette nødvendige ressurser til implementering og monitorering av prosess.

8. van Eijk MM, van Marum RJ, Klijn IAM, de Wit, N, Kesecioglu J, Slooter AJC. Comparison of delirium assessment tools in a mixed intensive care unit. Crit Care Med. 2009;37:1881-5.

9. Steis MR, Fick DM. Are nurses recognizing delirium? A systematic review. J Gerontol Nurs. 2008;34:40-8.

10. Pun BT, Ely EW. The importance of diagnosing and managing ICU delirium. Chest. 2007;132:624-36.

11. NHS/National Institute of Health and Clinical Excellence (NICE) [Internett]. Clinical Guideline 103. Delirium: diagnosis, prevention and management. London: National Institute for Health and Clinical Excellence, 2010. Tilgjengelig fra: http://guidance.nice. org.uk/CG103 (Nedlastet 10.10.2010).

12. Milisen K, Foreman MD, Wouters B, Driesen R, Gooderis J, Abraham IL et al. Documentation of delirium in elderly patients with hip fracture. J Gerontol Nurs. 2002;28:23-9.

13. Plaschke K, von Haken R, Scholz $M$, Engelhardt R, Brobeil A, Martin E et al. Comparison of the confusion assessment method for the intensive care unit (CAM-ICU) with the Intensive Care Delirium Sceening Checklist (ICDSC) for delirium in the critical care patients gives high agreement rate(s). sert praksis i helsefag, Senter for kunnskapsbasert praksis, Høgskolen i Bergen.

Takk til Norsk Sykepleierforbund og Norsk Sykepleierforbunds Landsgruppe for Intensivsykepleiere for økonomisk støtte i studietiden.
Intensive care med. 2008;34:431-36. 14. Van Rompaey B, Schuurmans MJ, Shortridge-Baggett LM, Truijen S, Elseviers M, Bossaert L. A comparison of the CAM-ICU and the NEECHAM Confusion Scale in the intensive care delirium assessment: an observational study in non-intubated patients. Critical Care [Elektronisk artikkel]. 2008; 12. Tilgjengelig fra: http://ccforum.com/ content/12/1/R16 (10.04.2009).

15. Ely EW, Inouye SK, Bernard GR, Gordon S, Francis J, May L et al. Delirium in Mechanically Ventilated Patients: Validity and Reliability of the Confusion Assessment Method for the Intensive Care Unit (CAM-ICU). JAMA. 2001;286:2703-10.

16. Ely EW, Margolin R, Francis J, May L, Truman B, Dittus R et al. Evaluation of delirium in critically ill patients: Validation of the Confusion assessment Method for the Intensive Care Unit (CAM-ICU). Crit Care Med. 2001;29:1370-7.

17. Flaatten H. Metodebok: Seksjon for intensivmedisin, Kirurgisk serviceklinikk. Bergen: Haukeland Universitetssykehus, 2009.

18. National Institute of Health and Clinical Excellence (NICE). Principles for best practice in clinicl audit. Oxon: 
Radcliffe Medical Press Ltd., 2002. 19. Seddon M, Buchanan J. Quality improvement in New Zealand healthcare. Part 3: achieving effective care through clinical audit. Journal of the New Zealand Medical Association [Elektronisk artikkel]. 2006:119:1239. Tilgjengelig fra: http://nzma.org.nz/ journal/119-1239/2108/(23.05.2010). 20. Nasjonalt kunnskapssenter for helsetjenesten. Sjekklister for kvalitetsvurdering av retningslinje. Tilgjengelig fra: http://www kunnskapssenteret no/ Verkt\%C3 \%B8y/Sjekklister+for+vurde ring+av+forskningsartikler. 2031. cms (Nedlastet 30.03.2010)

21. van den Boogaard M, Pickkers $P$, van der Hoeven H, Roodbol G, van Achterberg T, Schoonhoven L. Implementation of a delirium assessment tool in the ICU can influence haloperidol use. Crit Care [Elektronisk artikkel]. 2009;13:[7 s.] Tilgjengelig fra: http://ccforum.com/content/13/4/R131 (04.10.2009).

22. Pun BT, Gordon SM, Peterson JF Shintani AK, Jackson JC, Foss J et al. Large-scale implementation of sedation and delirium monitoring in the intensive care unit: a report from two medical centers. Crit Care Med. 2005;33:1199205

23. Page VJ, Navarange S, Gama S, McAuley DF. Routine delirium monitoring in a UK critical care unit. Crit Care [Elektronisk artikkel]. 2009:13:[6 s.] Tilgjengelig fra: http://ccforum.com/ content/13/1/R16 (04.04.2009).

24. Riekerk B, Pen EJ, Hofhuis JGM, Rommes JH, Schultz MJ, Spronk PE. Limitations and practicalities of CAMICU implementation, a delirium scoring system, in a Dutch intensive care unit. Intensive Crit Care Nurs. 2009:25:242-9. 25. Forsetlund L, Bjørndal A, Rashidian A, Jamtvedt G, O'Brien MA, Wolf $F$ et al. Continuing education meetings and workshops: effects on professional practice and health care outcomes. Cochrane Database of Systematic Reviews [Elektronisk artikkel]. 2009 CD003030.D01:10.1002/14651858. CD003030.pub2:[113 s.]. Tilgjengelig fra: http://mrw.interscience.wiley.com/ cochrane/clsysrev/articles/CD003030/ pdf_fs.html (18.01.2009).

26. Shojania KG, Jennings A, Mayhew A, Ramsay CR, Eccles MP, Gromshaw $J$. The effects of on-screen, point of care computer reminders on processes and outcomes of care. Cochrane Database of Systematic Reviews [Elektronisk artikkel]. 2009. CD001096. DOI:10.1002/14651858.CD001096.pub2. Tilgjengelig fra: http://www.mrw.interscience.wiley.com/cochrane/clsysrev/ articles/CD001096/frame.html (Nedlastet 14.04.2011).

27. Farmer AP, Légaré F, Turcot L,
Grimshaw J, Harvey E, McGowan JL, Wolf F. Printed educational materials: effects on professional practice and health care outcomes. Cochrane Database of Systematic Reviews [Elektronisk artikkel]. 2008. CD004398. DOI: 10.1002/14651858.CD004398.pub2: [36 s.] Tilgjengelig fra: http://mrw.interscience.wiley.com/cochrane/clsysrev/ articles/CD004398/frame.html (Nedlastet 18.04.2009).

28. Jamtvedt G, Young J, Kristoffersen DT, O'Brien MA, Oxman AD. Audit and feedback: effects on professional practice and health care outcomes. Cochrane Database of Systematic Reviews [Elektronisk artikkel]. 2006. CD000259. DOI:10.1002/14651858. CD000259. pub2: [113 s.] Tilgjengelig fra: http://www.mrw.interscience. wiley.com/cochrane/clsysrev/articles/CD000259/frame.html (Nedlastet 18.04.2009).

29. Flottorp SA, Jamtvedt G, Gibis B, McKee M. Using audit and feedback to health professionals to improve the safety of health care. København, World Health Organization on behalf of the European Observatory on Health Systems and Policies [Elektronisk artikkel]. 2010. Tilgjengelig fra: http:// www.euro.who.int/en/what-we-do/ data-and-evidence/health-evidencenetwork-hen/publications/2010/ using-audit-and-feedback-to-healthprofessionals-to-improve-the-qualityand-safety-of-health-care (13.09.2010). 30. Carey RG, Lloyd RC. Measuring quality improvement in healthcare. A guide to statistical process controll applications. Milwaukee: American Society for Quality, 2001.

32. Helsedirektoratet / Diagnosekodeverk ICD-10 [Internett]. Oslo: Helsedirektoratet: 2011. Tilgjengelig fra: http://www.helsedirektoratet.no/ finansiering/medisinsk-koding-ogkodeverk/icd-10/Sider/default.aspx (Nedlastet 20.02.2012).

33. Altman DG. Practical statistics for medical research. Boca Rota: Chapman \& Hall, 1999.

34. Bion JF. Approaches to improving the reliability and safety of patient care. I: Chiche J-D, Moreno R, Putensen C, Rhodes A, red. Patient Safety and Quality of Care in Intensive Care Medicine. Berlin, Medizinisch Wissenschaftliche Verlagsgesellschaft mbH \& Co; 2009. s. 487-95.

35. Devlin JW, Fong JJ, Howard EP, Skrobik Y, McCoy N, Yasuda C et al. Assessment of delirium in the intensive care unit: nursing practices and perceptions. Am J Crit Care. 2008:17:55565

36. Flagg B, Cox L, McDowell S, Mwose JM, Buelow JM. Nursing iden- tification of delirium. Clin Nurse Spec. 2010;24:260-6.

37. Pronovost A, Rubenfeldt GD. Quality in critical care. I: Chiche J-D, Moreno R, Putensen C, Rhodes A, red. Patient Safety and Quality of Care in Intensive Care Medicine. Berlin: Medizinisch Wissenschaftliche Verlagsgesellschaft mbH \& Co; 2009. s. 127-39. 38. Donabedian A. The quality of care: How can it be assessed? JAMA. 1988;260:1743-8

39. Grimen H. Debatten om evidensbasering -noen utfordringer. I: Grimen $H$, Terum LI, red. Evidensbasert profesjonsutøvelse. Oslo, Abstrakt forlag. 2009:191-221.

40. Devlin JW, Marquis F, Riker RR Robbins T, Garpestad E, Fong JJ et al. Combined didactic and scenariobased education improves the ability of intensive care unit staff to recognize delirium at the bedside. Crit Care [Elektronisk artikkel]. 2008; 12: [6 s.]. Tilgjengelig fra: http://ccforum.com/ content/12/1/R19 (12.05.2009).

41. O'Brien MA, Rogers S, Jamtvedt G, Oxman AD, Odgaard-Jensen J, Kristoffersen DT et al. Educational outreach visits: effects on professional practice and health care outcomes. Cochrane Database of Systematic Reviews [Elektronisk artikkel]. 2007. CD000409. DOl: 10.1002/14651858.CD000409.pub2: [81 s.] Tilgjengelig fra: http://www.mrw. interscience.wiley.com/cochrane/ clsysrev/articles/CD000409/frame. html (Nedlastet 08.05.2010).

42. Flodgren $G$, Parmelli $E$, Doumit G, Gattellari M, O'Brien MA Grimshaw J et al. Local opinion leaders: effects on professional practice and health care outcomes. Cochrane Database of Systematic Reviews [Elektronisk artikkel]. 2007. CD000125. DOI 10.1002/14651858.CD000125.pub3: [70 s.]. Tilgjengelig fra: http://mrw.interscience.wiley.com/cochrane/clsysrev/articles/CD000125/frame.html (25.04.2011)

43. Grol RPTM, Bosch MC, Hulscher MEJL, Eccles MP, Wensing M. Planning and studying improvement in patient care: the use of theoretical perspectives. Milbank Q. 2007; 85: 93-138.

44. Borbasi S, Jackson D, Lockwood C Undertaking a clinical audit. I: Courtney M, McCutcheon $\mathrm{H}$, red. Using evidence to guide nursing practice. Chatswood Churchill Livingstone / Elsevier; 2010. s. 113-31.

Les kommentaren på side 369 》> 